УДК: 821.163.41.09 Karadžić V. S.(049.32)

ДОИ: https://doi.org/10.46630/gsrj.18.2020.08

\title{
БОШКО СУВАЈЏИЋ \\ Къига о вуку. Београд: издавачко предузеће Албатрос плус, 2018.
}

Кюига о Вуку објављена на двестагодишњицу Вуковог Рјечника на симболичних двестотинак страна складишти предговор и још петнаест одељака као одговор на једнак број тврдњи предочених у Пледоајеу (5-11), од којих свака наглашава ауторов јасан став: за и за Вука. Бошко Сувајџић поново сучељава Вука и нас, Вука и свет, нас и с(а)ве(с)т. О Рјечнику, пак, пише као песник о књизи, самониклој и свезнадарној. Са крошњом у апстрактним појмовима, са кореном у предметном језику. Стабло јој је чворновато и квргаво, опсиено и жилаво, упрегнуто у плуг језика, препуно звекета материјалних појмова, покућства речи, ларме обичаја и веровања, силовитог струјања народног живота.

Први одељак Српска народна поезија у свету - свет у српској народној поезији (12-22) сведочи о Вуковом представљању Европе Србији и Србије Европи, предочавајућипреводенашег народног стваралаштва на италијански, немачки, француски, енглески, руски, украјински, пољски, чешки, мађарски и бугарски језик, и наводећи бројне разлоге због којих су научници из разних земаља посвећивали пажњу нашем језику и нашој књижевности, култури и историји. О истом Бошко Сувајџић наставља да пише и у следећем одељку Вук и предвуковски записи (23-38) наглашавајући да је Вуку одговарало да се мисли о њему као о првом баштинику нематеријалног културног наслеђа. Вуков однос према традицији и претходећим и савременим изворницима осветљен је и расветљен. Ова два одељка као у огледалу пишу о рецепцији српске народне поезије у европском културном контексту. О утицајима Ерлангенског рукописа и рукописних зборника српске грађанске лирике на постанак и обликовање Вукове Пјеснарище из 1814. године аутор пише у одељцима Вукова Пјеснарииа као канон (39-53) и Вукова Пјеснарица као отворено дело (54-70). Бошко Сувајџић сагледава бројна истраживања грађе у Пјеснарици и њене подударности са поменутим изворницима, и кроз дијалог који успоставља, долази до закључака да Вук није био без пређашње лектире, али да му је неопходна даровитост помогла да већ у првом свом делу успостави канон целокупној будућој делатности и да тај канон и сам постане изворник, који ће привући интересовања романтичарске Европе. Одељак Обликовање немуштог - Српски рјечник (1818) у Вуковој Преписии (71-90) указује на настајање и рецепцију Вуковог Српског рјечника у српској културној средини и међу Словенима и у западној Европи. Вукова 
сабрана преписка незаобилазан је извор за анализу и тумачење његовог дела и најбоља и најсадржајнија хроника српског културног и политичког живота прве половине XIX века, открива живе и целловите људе [...] у свој својој биографској и аутобиографској пуноћи, како пише Сувајџић. На основу примера кореспонденције са великим бројем значајних руских научника и књижевника, у одељку Вук и Руси (91-112) пружају се и потврде Вукових блиских и сложених односа са Русима и Русијом, који су почели да се формирају и пре његовог одласка међу источне Словене. Бошко Сувајџић подсећа колики је значај имала руска песмарица народног стваралаштва у формирању Вука као књижевног посленика. Према сопственим сведочењима из 1814. године, њега је та песмарица, коју је у пртљагу донео из устаничке Србије у Беч, подстакла на размишљање и о сакупљању српских народних песама. У овом одељку аутор пребројава сва Вукова драгоцена књижевна и научна руска познанства и износи најзначајнија сведочанства у виду преписке. У одељку Вук и Французи (113-118) Сувајџић нам приближава Вукова интересовања за француске културне и политичке прилике, али и примере прихватања и интересовања за Вука у Француској. Одељак Срби сви и свуда (119-126) прати објављивање фототипског издања Вуковог Ковчежића из 1849. године са предговором Наде Милошевић-Ђорђевић и књиге Вук Стефановић Карацић, Срби сви и свуда: о книжевности и језику (предговори, критике, полемике, чланци, писма), коју је приредио Душан Иванић. У тексту се истиче да је Вук својим делом бранио духовно и језичко пространство Срба ма где се они налазили, што је неретко изазивало и велике политичке буре и скандале, јер је Вук језик сматрао најстаријим и најважнијим чиниоцем идентитета једног народа. Тридесетогодишња историја Вуковог превођења Новог завјета изнета је у одељку Вук и 1847 (126-145). Вукова преписка као доказ допуњена је аустријским полицијским и судским извештајима. Забрана и цензура на превод у Бечу је укинута следеће 1848. године, забране у Србији су укинуте тек двадест година после. Вукова преписка представља један од најважнијих извора за познавање порекла и историјата сакупљаног и објављиваног Вуковог материјала, као и биографија Вукових певача и приповедача. Одељак Вукови певачи у Вуковој Преписии (146-164) издваја преписку са Вуковим сарадницима - Вуком Поповићем, Вуком Врчевићем и Савом Мартиновићем. Ова преписка открива податаке о мање познатим певачима и приповедачима из Црне Горе. У одељку Вук $u$ Његош (165-183) Сувајџић пише о пријатељским и плодним књижевним односима ове двојице првака XIX века. То чини поново завирујући у Вукову преписку и издвајајући репрезентативне примере њихове блискости и оданости, особито на пословима око Вукових Пословища и превода Новог завјета и Његошевог Огледала српског и Горског вијенца. Одељак Андрић о Вуку (184-195) анализира Андрићеву есејистику о Вуку Караџићу, писану, како наводи Сувајџић, увек с поводом. При крају одељка наглашено је и 
присуство Вуковог стила и језика у основи Андрићевог, ипак, самосвојног стваралачког израза.

Коначно се појавио аутор достојан чашице разговора са Мешом Селимовићем, двеста година пошто је Вук Стефановић Караџић својим Рјечником откључао тамни вилајет народних предања и легенди и пустио најлепше приче да колају светом. Бошко Сувајџић у Кюизи о Вуку, или у књизи о нама самима, аргументовано и надахнуто подржава идеју Вуковог представљања српског народа као књижевног и увођења српске литературе y европску литературу, једновремено чувајући самобитност Срба и инсистирајући свагда на појмовима народно и српско. Сувајџићев резон за и за Вука предвиђа широк круг адресата и јасну мисију. Петнаест теза Пледоајеа, као и равно петнаест одељака Кьиге о Вуку, садрже аргументе који иду у прилог Вуковом поступку у научно-стручном и социјалном смислу. Последњи одељци Кюиге о Вуку биће први за даља трагања за знаменима Вуковог дела, како свој критички осврт на књигу насловљава позвани рецензент, историчар књижевности Миодраг Матицки. Надахнуто и присно дата су нам изворишта будућих чарања речима, која нас враћају ширинама мисли нашег народа и очовечавању света.

\author{
Кристина Р. Митић ${ }^{1}$ \\ Универзитет у Нишу \\ Филозофски факултет \\ Департман за србистику
}

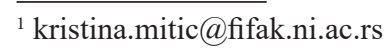

